\title{
The unique role of municipalities in integrated watershed governance arrangements: a new research frontier
}

\author{
María Mancilla García $^{1}$, Jacob Hileman $^{1}$, Örjan Bodin $^{1}$, Annika Nilsson $^{2}$ and Pedro Roberto Jacobi $^{3}$
}

\begin{abstract}
Local governments, or municipalities, play a key role in water governance around the world owing to the many administrative competencies they hold, ranging from water service delivery to urban planning. However, the ability of municipalities to carry out their competencies effectively depends in large part on the characteristics of the institutional arrangements in which they are embedded. In particular, the relationship between municipalities and watershed governance institutions has received little attention in the literature on polycentric and multilevel governance. Drawing on insights from diverse cases around the world, we argue that empirical research must pay closer attention to the links, or lack thereof, between municipalities and watershed governance institutions to improve the sustainability of water governance outcomes in practice. We identify a set of critical issues affecting municipalities' engagement in governance at the watershed scale that broadly apply across different contexts, and which we argue deserve more attention in future research: (1) disconnect and ambiguities of authority across hierarchical levels; (2) internal and external challenges to municipalities engaging in effective collaborations; (3) barriers to expanding the scope of traditional municipal affairs; and (4) misalignment of biophysical, institutional, and political timescales.
\end{abstract}

Key Words: basin councils; institutional fit; local governments; multilevel governance; polycentric governance

\section{INTRODUCTION}

Water governance ${ }^{[1]}$ paradigms, in particular integrated water resources management (IWRM), have historically emphasized planning approaches at the regional level, most often in the form of basin councils (Huitema et al. 2009, Baumgartner and PahlWostl 2013). For example, the European Water Framework Directive explicitly defined governance along watershed lines and divided the continent into 110 river basin districts (European Commission 2000). However, administrative competencies, such as the provision of water infrastructure, service delivery, and related administrative tasks, are typically held by local governments, or municipalities (Newig et al. 2016). This inherent tension has been brought to the fore globally as the growth in multistakeholder collaborative forms of governance, and in some cases associated decentralization efforts, have resulted in increasingly complex polycentric governance systems, characterized by the existence of multiple decision-making centers and involving many diverse public and private actors (Ostrom 2010). This tension is further reinforced by population growth and increased consumption, as well as climate change and other global phenomena that impact the quantity, quality, and distribution of water resources. For example, in response to a severe drought in 2014, the state governments of São Paulo, Minas Gerais, and Rio de Janeiro in Brazil elected to develop new infrastructure on the Paraíba do Sul River, which they did without first seeking the approval of the basin council (see also Mancilla García and Bodin 2019a). The presence of multiple centers of decision making for shared water resources, although important from the perspective of institutional fit, complicates the challenges municipalities must navigate as they carry out their administrative competencies.

The interconnectedness of water resources across local and regional scales magnifies the need for integrated governance approaches that account for interdependence within coupled social-ecological systems, specifically across political and hydrologic boundaries (Pahl-Wostl et al. 2011). Past and current attempts to address these issues, including IWRM, have had mixed success (Blomquist and Schlager 2005, Halbe et al. 2013). We argue that this is partly the result of failing to recognize the overarching importance of, and barriers to, municipal involvement in basin-level water governance institutions. The creation of basin councils constitutes a new decision-making center in water governance arrangements, and one which, in theory, serves to complement existing institutional structures at the local and regional levels. However, the result is a complex polycentric governance system in which many formally independent, but functionally dependent, centers of decision making exist, each with their own set of administrative competencies and responsibilities (Huitema et al. 2009). Municipalities are but one of these decision-making centers, yet they are key actors given their role in public service provision, and an explicit focus on their situation within complex and multilevel governance structures is warranted.

We draw on extensive experience from the field, in both weak and strong institutional settings alike, to elaborate on four key barriers to municipal involvement in watershed governance arrangements. Specifically, we present empirical insights from academic publications and legal and policy documents from the following: El Salvador and Nicaragua, as examples of countries with lower development profiles and relatively weak institutions; Sweden and the United States, as examples of highly developed countries with strong institutions; and Brazil and Peru, as examples of middleincome countries with stark inequalities in terms of economic and institutional development. We selected cases across an institutional development spectrum in which (1) there exist basinlevel governance institutions constituted at different points in time; (2) municipalities are invited, and in some cases mandated, to participate in these institutions; and (3) municipalities have direct competencies with regard to water management, e.g., water service provision. Our objective is not to compare all of these cases across the same set of variables, such as the specific water-

${ }^{1}$ Stockholm Resilience Centre, Stockholm University, Stockholm, Sweden, ${ }^{2}$ Department of Law, Uppsala University, Uppsala, Sweden, ${ }^{3}$ Institute of Energy and Environment, University of São Paulo, São Paulo, Brazil 
related competencies each municipality possesses, but rather to highlight common challenges, and we recommend future comparative studies systematically address similarities and differences in the challenges municipalities face across diverse contexts.

We provide a general overview of the role of municipalities in polycentric and multilevel watershed governance arrangements and highlight several important issues municipalities confront across a broad range of social-ecological contexts. We provide a brief background to the empirical cases and then discuss each of the identified issues using examples from the cases to illustrate how municipal involvement in basin-level governance institutions is a global challenge. Finally, we summarize the key findings and suggest a path forward for addressing these issues in future research.

\section{THE MUNICIPALITY-BASIN GAP IN WATER RESOURCES GOVERNANCE}

The unique characteristics of water set it apart from most other renewable natural resources and also complicate its governance. Water is an integral component of all ecosystems (the same watershed may even encompass many diverse ecosystems) and forms the backbone of human society as a key element of agriculture, industry, and many facets of daily life. On account of being a mobile resource, the same body of water may cross many different social, political, and administrative boundaries as it flows along its course. Furthermore, numerous human uses and interests overlap and compete for finite water resources. In agricultural irrigation schemes, for example, downstream irrigators are affected by the quantity and quality of water available after upstream irrigators have drawn water to meet their needs. This in turn may affect the quantity and quality of water available for other uses farther downstream in the watershed. In this manner, water is integrative by nature, and therefore, effective governance of water resources requires integrated governance across sectors, scales, and administrative levels (Lebel et al. 2013, Varis et al. 2014).

Against this social-hydrologic backdrop, administrative competencies and funding for water management activities are typically distributed on the basis of human-defined political boundaries, often at the municipal and/or national levels. These boundaries do not necessarily reflect the intertwined nature of socio-political and biophysical systems (Wyborn and Bixler 2013). Moreover, the overlap in administrative competencies, and the lack of clarity in the distribution of these competencies across levels of governance, presents coordination challenges and frequently leads to disputes over competencies. To add yet another layer of complexity, water governance arrangements are frequently organized such that different institutions are in charge of regulating specific aspects of water resources. For example, the regulation of water quality typically occurs at higher administrative levels, whereas the responsibility of meeting water quality standards often falls on lower administrative levels. In particular, the burden of providing service delivery and implementing water management plans is largely shouldered by municipalities.

Further complicating this already complicated policy and governance landscape is the relatively recent movement toward basin-level planning institutions. IWRM is often credited for inspiring this movement, and it is telling that the principles of
IWRM have been incorporated into many contemporary water policies around the world, by some estimates more than $80 \%$ of countries' national water policies (Cherlet 2012), including developed and developing countries alike (Beveridge and Monsees 2012). The overarching motivation behind IWRM is one of institutional fit, or the alignment of institutions with characteristics of the biophysical system being managed (Folke et al. 2007). In this regard, basin-level governance institutions were presumed to be the solution for coordinated and rational distribution of management activities and administrative competencies from an integrated social-hydrologic perspective (Lebel et al. 2005). By aligning governance structures with physical watershed boundaries, the effects of agriculture, industry, urban development, and all other land uses having an impact on water quantity and quality should, in theory, be better integrated into holistic planning. However, the reality is that municipalities have both maintained their administrative competencies at the local level and received the added burden of needing to engage in governance at the basin level. The failure to recognize that expanding municipal responsibilities would stretch typically thin resources even thinner has served to create additional obstacles to effective water resources governance.

\section{DIVERSE EXPERIENCES WITH MUNICIPALITIES AND BASIN-LEVEL GOVERNANCE ARRANGEMENTS}

The empirical insights we present cover world regions that vary widely in terms of their socio-political and biophysical contexts, as well as level of economic and institutional development. The cases were intentionally chosen to highlight the fact that many of the barriers to achieving the integration of municipalities within basin-level governance arrangements are present across contexts. Despite important differences in institutional design across countries regarding which actors are invited and/or mandated to participate in basin councils, a common denominator across the cases is that collaborative governance arrangements at the basin level bring together a heterogeneous set of local, regional, and national government actors; private water users, including industry and agriculture; and civil society organizations, such as nongovernmental organizations (NGOs) and both formal and informal community-based groups.

Sweden and the United States have been implementing IWRMinspired policies for nearly 20 years, and both countries count water governance institutions at the basin level. However, there is considerable variation in the levels of formalization of basin councils across U.S. states, and we specifically draw on the case of California. Brazil and Peru have historically adopted different approaches to water governance, although in recent years both have moved toward IWRM-inspired policies. Although the legal basis for basin councils has existed for more than two decades in Brazil (Presidência da República, Casa Civil, Subchefia para Assuntos Jurídicos 1997), these councils have not been implemented in all of the country's basins. Peru has also adopted IWRM principles in its national water policy and began establishing basin councils less than a decade ago (Autoridad Nacional del Agua 2009). El Salvador and Nicaragua draw heavily on IWRM principles (both countries explicitly refer to IWRM in their national water policies), but basin councils have only recently received formal legal backing. Implementation of these councils is ongoing, and existing councils vary widely in terms of their levels of institutionalization. 
The establishment of basin governance institutions in Sweden was codified and received institutional backing in 2000 through the European Water Framework Directive (European Commission 2000). The directive was subsequently implemented in Sweden in 2004, granting water governance responsibilities at the regional level to county administrative boards appointed as "water authorities" for their respective water districts. Municipalities participate in water governance in several ways; for example, some municipal officials hold decision-making functions in the water authorities as government-appointed expert members, but not formally as representatives of their own municipality, and all municipalities in a water district can participate in consultation procedures. In addition, the water authorities promote participation in water governance through their support to "water boards" (Swedish: Vattenråd), which constitute a diverse set of typically bottom-up driven platforms for collaboration engaging heterogeneous actors such as nonprofit organizations, NGOs, private landowner representatives, and municipalities.

In the U.S. state of California, the establishment of basin governance institutions was legislatively enacted in 2002 with the passage of the Integrated Regional Water Management (IRWM) Planning Act (California State Legislature 2002). The act mandated the establishment of multistakeholder regional water governance groups, including municipal governments, private interest groups, disadvantaged communities, and other stakeholder groups, and provided funding to support the formation of these groups. Although decision-making authority is granted to each IRWM planning group, the California Department of Water Resources and State Water Resources Control Board are charged with the administration of the overall IRWM program, which presently covers $87 \%$ of the state and accounts for $99 \%$ of the population (California Department of Water Resources 2019).

In Brazil, water governance institutions at the basin level have been implemented since the 1990 s, coinciding with the initial development of the IWRM approach. Basin councils are complemented by other participatory institutions at the state level that deal with water resources legislation. Both basin and statebased governance institutions bring together civil society organizations, government entities including municipalities, and private water users to engage in structured, deliberative decisionmaking processes. However, it is basin councils that are responsible for developing basin plans, including establishing water access rights and payment for water use by large private users, e.g., industry or sewerage treatment.

Similar IWRM-inspired basin governance institutions have also been created in Peru, but in contrast with Brazil, these are the only instantiations of participatory institutions where municipalities and other public and private stakeholders are able to interact and deliberate on water policy and governance issues. The law mandates who gets to participate in these institutions, and therefore, they are more restrictive. Watershed governance institutions were instituted relatively recently in Peru, beginning in 2011 and continuing to the present, and they are exclusively advisory bodies with no regulatory authority. Water governance in the country is overseen by the National Authority of Water, which is composed of multiple deconcentrated agencies whose jurisdiction does not correspond to local or regional divisions, nor to the territories covered by basin councils. This hierarchical structure of public administrative agencies is staffed with officers from the Ministry of Agriculture.

El Salvador and Nicaragua draw heavily on IWRM in their national water plans, and both countries similarly established laws devolving planning authority to municipalities in the early 1990s. However, basin councils are a more recent development. In El Salvador, the passage of the broad Environmental Law in 1998 (Asamblea Legislativa, Republica de El Salvador 1998) provided a legal basis for the establishment of basin councils, yet it does not actually mandate basin councils be established. However, a new water law currently being debated would require the formation of regional water governance entities based around watersheds. At present, basin councils are formed on an ad hoc basis, and although municipalities play a role in these councils, their participation is not mandated and their decision-making authority is not defined.

In Nicaragua, the passage of the National Water Law in 2010 (Normas Jurídicas de Nicaragua 2010) provided the legal architecture for establishing basin councils and, in contrast with El Salvador, mandated their formation. The law defines who must participate in the decision-making body of the basin council, and municipal representation from every locality in the basin is required. However, more investigation is needed to determine if this is actually true in practice and whether it has brought about any changes in the decision-making process and perceptions of procedural fairness.

\section{CHALLENGES CONFRONTING MUNICIPALITIES IN BASIN-LEVEL GOVERNANCE ARRANGEMENTS}

\section{Disconnected and ambiguous authority across and within administrative levels}

The sharing of administrative competencies is not always smooth; none of the empirical cases spell out unambiguously the roles of, and relationships between, municipalities, basin-level institutions, and other actors in water governance arrangements. When public policy is nonexistent, not enforced, or simply fails to articulate the relationship between municipalities and higher-level governance institutions, municipalities may have difficulties carrying out their basic set of administrative competencies, let alone addressing water governance issues at the basin scale. Under these circumstances, municipalities may revert to focusing exclusively on management within their own territories, and this is true of both weak and strong institutional settings.

In El Salvador, there is no public policy addressing how administrative responsibilities should be shared across municipalities within the same watershed. A related challenge is that the regulatory responsibility for water resources is often split among multiple agencies based on specific water uses, e.g., agriculture, environment, household use, and so forth. For example, the Ministry of Environment is almost entirely disconnected from public policy around water supply provision; this is the domain of the National Aqueduct and Sewerage Administration. However, one of the biggest challenges to providing safe drinking water in El Salvador is environmental degradation, which is within the purview of the Ministry of Environment, and addressing this issue requires integrated governance at the watershed scale. How municipalities are 
supposed to carry out their administrative competencies within this fragmented institutional landscape is unclear, and the end result is the absence of meaningful communication and coordination among municipalities and between municipalities and state actors.

In Brazil, the National Law on Water Resource Management (Presidência da República, Casa Civil, Subchefia para Assuntos Jurídicos 1997) does not delegate any specific administrative competencies to municipal governments, yet they are broadly responsible for land use planning and management actions within their territories (Ribeiro 2015). The lack of links between these two areas of public policy (Fracalanza et al. 2009, Fabbro Neto and de Souza 2017) has both served to marginalize the role of municipalities in water governance and, in some cases, enabled them to develop policies that directly violate national regulatory statutes or those of the basin. For example, construction in critical watershed areas is forbidden in Brazil, but some municipalities have ignored this interdiction (Malheiros et al. 2013). Although the inclusion of municipal governments in basin councils marks an important attempt to integrate municipal perspectives into higher-level formal decision-making processes, empirical studies have documented how the actual participation of municipalities in basin councils is weak (Britto and Formiga-Johnsson 2011).

In Peru, municipal participation in basin councils is similarly weak, which is partly explained by the fact that all municipalities within an administrative region have only one shared representative in the council. For example, the basin council of Chancay-Lambayeque counts two municipal representatives, one representing all municipalities in the region of Cajamarca and one representing all municipalities in Lambayeque. Building council representation along regional boundaries disregards upstream and downstream basin dynamics, which is a factor that often leads to tension and conflict between municipalities.

In Latin America more generally, an extensive body of theoretical and empirical literature has evaluated decentralization initiatives (Gray Molina 2004, Cameron 2009, Kauneckis and Andersson 2009), but not enough attention has been given to the relations between municipalities and watershed governance institutions. The literature has primarily focused on political competition across formal government levels, i.e., national, state, and municipal, yet the case of water management presents a specificity respective to other decentralized competencies. This collective body of research on the Latin American region addresses the obstacles municipalities must overcome as a result of decentralization initiatives but has not evaluated the far-reaching impacts this has on municipalities' capacities to fulfill their public mandates and engage with basin councils and other actors in collaborative governance arrangements. In particular, the broad literature on decentralization has favored a focus on issues of legitimacy and democratic norms, and human resources and fiscal capacities, but not on how these issues reverberate through complex systems of water governance.

In Sweden, municipalities participate in water "delegations," i.e., the decision-making arm of the water authorities, which have the power to set water quality standards, approve management plans, and provide guidance during ongoing management activities. However, municipalities are only appointed as experts in these water delegations, not as representatives for their municipalities. Furthermore, given that each delegation consists of 11 members, and may also include other actors, such as civil servants, academics, environmental consultants, and business representatives, not all municipalities in a given basin are necessarily represented in the water delegations. The members of these delegations are appointed by the national government, and they are chaired by the county governors (Ministry of Finance, Government of Sweden 2017, Ministry of the Environment and Energy, Government of Sweden 2017a). The water delegations' decisionmaking process in important management decisions begins with a consultation round, in which anyone, including municipalities and the public at large, can comment on a given proposal. Input from municipalities can lead to revision and supplementation of the decision-making materials before the final decision. Nonetheless, municipalities typically function as "executors" of these measures and plans, although they still retain authority and autonomy in relation to interrelated policy areas, such as land use planning and water service delivery. How to reconcile these responsibilities with what municipalities are directed to do by the water authorities often remains ambiguous.

\section{Internal and external challenges to municipalities engaging in effective collaborations}

Municipalities are charged with performing a broad range of water management activities and have numerous administrative responsibilities; however, they are not always internally structured to manage complex social-ecological issues spanning sectors and administrative boundaries. Furthermore, municipal actors are rarely focused on water resources alone and must juggle any number of other topics and tasks that compete for their time and focus (Mancilla García and Bodin 2019b). It is also important to recognize that municipal governments do not exist in isolation; on the contrary, they are affected by a multitude of interests from both within and outside their territories. However, municipalities typically do not have direct authority to address issues that originate from reaches of the basin located outside their municipal borders. For these reasons, municipalities rely on collaborations with other actors to help address a range of water management issues.

To address the challenges posed by the many varied and competing interests present in collaborative basin governance arrangements, one way public and private actors responded in Sweden was to create collaborative issue-based organizations outside the system of formal water governance institutions. These efforts typically are spawned through collaboration between municipalities, state and regional authorities, and even local businesses and other interest groups, with the common goal of furthering shared interests related to water governance. These collaborative organizations are intended to complement, not provide alternatives to, formal water governance institutions, and the establishment of many of these organizations even predates the European Water Framework Directive. In some instances, however, these issue-based collaborative organizations have been transformed into water boards and integrated within the formal water governance system. In general, these entities are considered central to the Swedish water governance system, both in terms of their management activities locally and the local knowledge they provide to basin governance institutions.

Both water boards and issue-based collaborative organizations in Sweden are perceived by the water authorities as central to achieving water policy and management goals; they provide a key 
link between relevant public authorities, concerned actors, and interest groups, as well as an arena for influencing water governance decision-making processes. Furthermore, formal water authorities often depend on water boards and collaborative organizations to provide local knowledge, reflecting the collective expertise of the diverse participating actors. For example, the water board for Svartån's catchment in central Sweden was established to increase awareness of, and education about, specific water-related problems in the region, such as maintaining steady water flows and biological diversity. The board's members consist of representatives from industry, farming, and forestry, as well as nonprofit organizations and municipalities. A key function of the board is to arrange activities for its members, as well as the public at large, such as educational field trips on the theme of lake restoration, training in environmentally friendly drainage and ditching practices, or dialogue meetings with local farmer organizations. Through stakeholder input during activities and meetings, the board is able to advocate for particular issues facing individual municipalities during formal basin- or higher level decision-making processes. However, the Svartån's water board is not a public authority (no water boards in Sweden are public authorities) but functions as an advisory body that can bring important water issues to the attention of relevant authorities and decision makers. Hence, the water board does not actively take part in formal decision-making processes.

The movement toward participatory basin-level planning and related forms of collaborative governance has complicated the socio-political and institutional landscape by further increasing the number and diversity of stakeholders and other interest groups that municipalities must consider when making water management decisions. Hence, the ability of municipalities to address, internally and/or by means of wide-spanning collaborations, complex issues imposed on them through regulations from higher levels of government, or by large and influential stakeholders, may be limited. This, in turn, limits the ability of meeting management goals within a municipality, as well as achieving policy outcomes at scale throughout an entire basin.

In California, a survey of stakeholders in the San Francisco Bay Area IRWM planning region indicated that engaging with municipalities composed of a large number of disadvantaged communities ranked last out of seven core IRWM management goals (Lubell and Lippert 2011). The inclusion of representatives from disadvantaged communities in IRWM planning processes is required by law (California State Legislature 2002), yet within the institutional structure of the Bay Area IRWM planning committee, either the incorporation of disadvantaged communities was largely overlooked or decisions made by the committee did not lead to improved water governance outcomes for these municipalities. This illustrates how different, albeit overlapping, goals can be disconnected in practice across hierarchical administrative levels. Although disadvantaged communities may be well represented at the municipal level, this has not necessarily translated to representation in watershed governance institutions. Additionally, in spite of the fact that most stakeholders generally felt IRWM improved collaboration among municipalities and other actors through the institution of multistakeholder planning processes, the survey also indicated that many believed IRWM planning processes were dominated by a narrow set of historically powerful water interests (Lubell and Lippert 2011).

Taken together, these examples illustrate how municipalities often engage in various types of vertical collaborations across hierarchical administrative levels, as well as horizontal and even internal collaborations. Furthermore, these different forms of collaboration typically entail different mandates, roles, and objectives. Municipalities are, however, often organized into semiautonomous administrative units, which can emerge and evolve over time. Thus, a key challenge for municipalities is to coordinate their collaborations internally to make the best use of their numerous engagements in collaborations with other actors. Because their organizational structure may reflect the historical status quo as opposed to being designed to carry out such complex and cross-sectorial management activities and administrative tasks efficiently, this is clearly a difficult task. In the absence of close coordination and communication, semiautonomous municipal units may therefore not be able to address water resource dilemmas from a holistic perspective.

\section{Barriers to expanding the scope of municipal water management activities}

When it comes to resources for implementing water management activities, municipalities are in a relatively unique position; although they have taxation capacity, they also typically receive budget delegations from the central state. To fulfill their competencies, such as drinking water service provision and wastewater management, municipalities would, in theory, have recourse to their own taxation prerogatives. However, this is often costly, not only financially but also politically, because it would involve an increase in taxes. In the lead-up to elections, this is not an appealing strategy for municipal candidates, and it often encourages them to seek support from the state to renovate existing, or build new, infrastructure. These challenges are only further magnified when municipalities are required to expand the scope of their activities to address the basin level.

In Sweden, municipalities have many possibilities to finance water management tasks, at least on paper. Aside from their taxing authority, municipalities also finance water services directly through fees levied on consumers of public water supplies (Ministry of the Environment and Energy, Government of Sweden 2006). Regulations within the general environmental code also give municipalities supervisory authority, e.g., monitoring industries that discharge effluent into receiving water bodies, under which they are able to secure additional financing through collecting fees from the entities requiring supervision (Ministry of the Environment and Energy, Government of Sweden 1997, $1998 a, b)$. In reality, however, securing full financing of municipal water management activities through taxes and fees is politically difficult. Large variations in municipal fees have been reported (Ministry of the Environment and Energy, Government of Sweden 2017b), and some municipalities have found it incredibly difficult to finance necessary upgrades to existing infrastructure (Naturvårdsverket 2012).

In cases in which municipalities possess very few financial resources and/or do not have access to financing, engaging with basin councils and other higher level actors is both a challenge and a potential opportunity (Fabbro Neto and de Souza 2017). In Brazil, a recent strategy put forward by basin councils seeks to 
develop programs of interest to municipalities, e.g., providing loans and other support for wastewater treatment and similar infrastructure projects, to encourage municipal engagement. Basin councils may have more access to funding sources, which can help municipalities gain access to previously inaccessible funding opportunities. This is the case throughout much of Central America, including El Salvador and Nicaragua, which suggests a common reality across countries on the middle and lower parts of the development spectrum. Additionally, in Brazil, where basin councils receive some of their own funding through payments for water use, basin councils can use their revenue to help municipalities develop a range of projects, such as the construction of sewage treatment plants.

In Nicaragua, laws regulating the management of water resources have become an obstacle to municipalities seeking to invest in water funds, public-private partnerships, and other mechanisms that would provide funding for scaling up governance activities to the watershed scale. For example, several municipalities around Matagalpa were seeking the help of NGOs and the Ministry of Aqueducts and Sewer Systems to establish a watershed fund that would be paid into by local coffee producers and millers, large bottling companies, and the municipal water supply agency. In spite of Nicaragua having laws guiding the establishment of public-private partnerships, it was not possible for the municipal water supply agency to pay into a fund it did not directly manage. Hence, although there was interest among municipal governments to manage water resources, and especially sources of contamination, within the watershed as a whole, rigid laws governing the actions of municipal actors made this impossible. In these situations, NGOs have had to seek alternative funding mechanisms, or wade into public policy advocacy, to establish water funds and other payment schemes for environmental services to finance watershed governance across municipal boundaries.

In El Salvador, it is relatively easy to establish basin councils, and there has been a big push from NGOs to create basin councils, as evidenced by a growing number of these groups, including the Lake Ilopango Watershed Association and the Gulf of Fonseca Watershed Association. However, municipalities remain quite weak and often lack essential resources, and many NGOs do not find it pertinent to provide direct aid and institutional support to municipalities. The reason NGOs are often not willing to undertake close collaboration and extensive capacity-building efforts with local governments is precisely because they do not want to be perceived as being aligned with governmental bodies, which may complicate their work as "nongovernmental" organizations. This is a considerable issue in El Salvador, given it receives significant international development aid and is home to a large number of international NGOs. As a result, NGOs in the country often focus on basins, which represent biophysically delineated territories that are ostensibly nonpartisan, but it can be difficult to empower these councils to make binding decisions given the lack of relevant public policy and/or strong enforcement mechanisms.

\section{Misalignment of biophysical, institutional, and political timescales}

The challenges presented by complex multilevel water governance systems may be readily overcome by some municipalities and may be sources of constant conflict and barriers to effective governance in others (Hileman et al. 2016, LaVanchy et al. 2017). To further complicate this issue, municipalities are subject to pressure from a multitude of interest groups, including partisan political groups, and must grapple with both the social and ecological consequences of the decisions they make. It is important to remember that decisions involving the distribution and use of finite water resources are inherently political decisions, and municipal decisions may be very different as a result of administrative turnover following local elections. Consequently, municipalities may be less willing to invest in long-term and largescale programs that require substantial investments and continuity over time or that do not demonstrate immediate results (Mancilla García 2017). Within this dynamic, bridging short-term political horizons to accomplish what is needed in a watershed governance platform is a difficult task.

As a result of this misalignment, municipalities across diverse social-ecological contexts are often faulted for making decisions perceived as being detrimental to the environment to satisfy social and political interests. For example, during a mining conflict in the 2000s, the Swedish municipality of Gotland was torn between the two aims of supporting regional economic development and safeguarding the quality of drinking water (Anshelm et al. 2018). However, it is at the municipal level where citizens are most readily able to be involved in water management or at least to help steer the direction of decisions made by municipal actors. In addition to our own experiences in the field, there are recent examples of citizen involvement in municipal processes leading to improved environmental outcomes (Horsbøl 2018), but future research should specifically examine this phenomenon in the context of water resources governance.

In El Salvador, municipal elections occur every 3 years, whereas water governance is an ongoing and long-term endeavor. In the municipalities of Comasagua, Tamanique, and La Libertad, respectively located in the upper, middle, and lower reaches of the Río Grande watershed, there is a growing recognition of deteriorating water supply quality, especially in the lower watershed. However, short 3-year terms mean mayors are almost exclusively focused on infrastructure projects with immediate and widely visible results, e.g., road building and water system repairs, not investing in institutional capacity building at the basin level, which might facilitate incremental improvements to the larger watershed over time. Municipalities often get no "political points" for improving the environment, and finding ways, for example, to make reductions in non-point-source pollution visible would make it easier to implement such changes. However, even in this case, municipalities in El Salvador often do not have the technical capacity to determine which set of management activities will have the biggest overall impact and rely on NGOs and other actors with technical expertise for guidance in decision-making processes.

In contrast, municipalities in Sweden generally remain reasonably stable even during transitions in municipal government representation; although politically appointed positions may change, the overall administration within local government offices does not necessarily change. In this way, continuity is maintained at the day-to-day administrative level, whereas mid- to long-term project planning may be subject to new perspectives and policy 
proscriptions. However, recent research also suggests there may be differences between the objectives of elected officials and career bureaucrats at the municipal level, which should be considered in future research (Pierre et al. 2017). Additionally, many municipalities in Sweden are experiencing problems not so much because of political dynamics, but in recruiting and keeping competent civil servants. In some instances, municipalities will hire outside technical consultants, which in turn risks poor integration of water management activities with other policy areas within the municipality.

\section{CHARTING A PATH FORWARD}

We argue that municipalities are cornerstones in polycentric and multilevel watershed governance arrangements owing to their unique administrative competencies and status as public service providers and formal decision-making centers. As such, municipalities must contend with a number of competing tasks and diverging interests as they work to carry out their administrative competencies. Additionally, it is essential to understand municipalities in relation to other institutions in multilevel water governance arrangements; the possibilities for municipal action may be constrained or enhanced by national legislation and funding decisions made by basin councils or other regional governance institutions. However, it is municipalities that ultimately make many of the day-to-day and often difficult decisions that not only affect their municipal territories but potentially affect other territories farther downstream in the basin.

We specifically highlight four areas, or barriers, where further research on the relationship between municipalities and basinlevel water governance institutions is needed: (1) disentangling how administrative competencies are shared by municipalities, basin councils, and other institutions with overlapping mandates, both within and across hierarchical levels; (2) achieving effective collaboration between municipalities and other actors to address issues that originate both within and outside of municipal boundaries; (3) identifying financial and regulatory obstacles to municipal engagement in basin-level planning processes; and (4) finding ways to reconcile short- and long-term biophysical, institutional, and political dynamics.

By presenting empirical insights from six countries with diverse socio-political and biophysical contexts, and that vary across an institutional development spectrum, we illustrate how municipalities broadly must overcome these four barriers to engage effectively in basin-level water governance institutions. However, that is not to say these are the only issues municipalities face in multilevel water governance arrangements. More research should additionally be done to explore the links between traditional municipal competencies, such as water service provision, and a more holistic understanding of water governance. The lack of clarity concerning the links between municipal water management activities and environmental governance more broadly results in municipalities assuming considerable workloads, which can stretch typically thin resources even thinner. Future studies should also explicitly adopt a comparative research design that aims to untangle what differences in administrative competencies lead to in terms of municipal engagement in basin-level governance institutions and, ultimately, in terms of policy and management outcomes.
[1] We use "water governance" to refer to water management activities across administrative levels and actor types, whereas we reserve the term "water management" for municipal interventions on water resources.

Responses to this article can be read online at: http://www.ecologyandsociety.org/issues/responses. php/10793

\begin{abstract}
Acknowledgments:
We would like to thank the GRAID program at the Stockholm Resilience Centre for support to organize a workshop in Stockholm on "collaboration and conflicts in complex water governance systems across a development gradient," which planted the seeds for this paper. M. Mancilla Garcia has received funding from the European Union's Horizon 2020 research and innovation program under Marie Sklodowska-Curie grant agreement no. 660394. Ö. Bodin acknowledges support from the Swedish Research Council and Formas. J. Hileman acknowledges the help of Paul Hicks.
\end{abstract}

\section{LITERATURE CITED}

Anshelm, J., S. Haikola, and B. Wallsten. 2018. Politicizing environmental governance - a case study of heterogeneous alliances and juridical struggles around the Ojnare Forest, Sweden. Geoforum 91:206-215. http://dx.doi.org/10.1016/j. geoforum.2018.03.003

Asamblea Legislativa, Republica de El Salvador. 1998. Ley del Medio Ambiente: Ley 233. Republica de El Salvador, San Salvador, El Salvador. [online] URL: https://www.asamblea.gob. $\underline{\text { sv/decretos/details/406 }}$

Autoridad Nacional del Agua. 2009. Ley de Recursos Hídricos: Ley $N^{\circ}$ 29338. Ministerio de Agricultura y Riego, República del Perú, Lima, Perú. [online] URL: http://www.ana.gob.pe/ media/316755/leyrh.pdf

Baumgartner, T., and C. Pahl-Wostl. 2013. UN-Water and its role in global water governance. Ecology and Society 18(3):3. http:// dx.doi.org/10.5751/ES-05564-180303

Beveridge, R., and J. Monsees. 2012. Bridging parallel discourses of Integrated Water Resources Management (IWRM): institutional and political challenges in developing and developed countries. Water International 37(7):727-743. http://dx.doi. org/10.1080/02508060.2012.742713

Blomquist, W., and E. Schlager. 2005. Political pitfalls of integrated watershed management. Society \& Natural Resources 18(2):101-117. http://dx.doi.org/10.1080/08941920590894435

Britto, A. L., and R. M. Formiga-Johnsson. 2011. Gestão Participativa e Integrada das Águas na Região Metropolitana do Rio de Janeiro: Uma Análise do Funcionamento dos Comitês de Bacia Hidrográfica. Pages 239-249 in VIII Congreso Ibérico de Gestão e Plaeamento da Água (Lisboa, 2013). Fundación Nueva Cultura del Agua, Zaragoza, Spain.

California Department of Water Resources. 2019. Integrated regional water management: IRWM grant programs. State of 
California, Sacramento, California, USA. [online] URL: https:// water.ca.gov/Programs/Integrated-Regional-Water-Management

California State Legislature. 2002. SB 1672, Costa. Integrated Regional Water Management Planning Act of 2002. State of California, Sacramento, California, USA. [online] URL: http:// www.leginfo.ca.gov/pub/01-02/bill/sen/sb 1651-1700/ sb 1672 bill 20020921 chaptered.html

Cameron, J. D. 2009. 'Development is a bag of cement': the infrapolitics of participatory budgeting in the Andes. Development in Practice 19(6):692-701. http://dx.doi. org/10.1080/09614520903026835

Cherlet, J. 2012. Tracing the emergence and deployment of the 'integrated water resources management' paradigm. Pages 1-31 in Proceedings of the 12th EASA Biennial Conference (Nanterre, France, 10-13 July 2012). Department of Third World Studies, Ghent University, Ghent, Belgium. [online] URL: http://hdl. handle.net/1854/LU-2964994

European Commission. 2000. Directive 2000/60/EC of the European Parliament and of the Council establishing a framework for community action in the field of water policy. Official Journal of the European Communities L327:22.12.2000.

Fabbro Neto, F., and M. P. de Souza. 2017. Leitura integrada da gestão dos recursos hídricos com o uso do solo em Caraguatatuba (SP). Engenharia Sanitaria e Ambiental 22(5):853-862. http://dx. doi.org/10.1590/s1413-41522017154955

Folke, C., L. Pritchard, F. Berkes, J. Colding, and U. Svedin. 2007. The problem of fit between ecosystems and institutions: ten years later. Ecology and Society 12(1):30. http://dx.doi.org/10.5751/ ES-02064-120130

Fracalanza, A. P., V. N. de O. Campos, and P. R. Jacobi. 2009. Governança das águas da Região Metropolitana de São Paulo (Brasil): o caso do Comitê de Bacia Hidrográfica do Alto Tietê. Pages 57-81 in P. R. Jacobi and P. A. Sinisgalli, editors. Dimensões político institucionais da governança da água na América latina e Europa. Annablume Editora, São Paulo, Brazil.

Gray Molina, G. 2004. The politics of popular participation in Bolivia, 1994-1999. Dissertation. University of Oxford, Oxford, UK.

Halbe, J., C. Pahl-Wostl, J. Sendzimir, and J. Adamowski. 2013. Towards adaptive and integrated management paradigms to meet the challenges of water governance. Water Science \& Technology 67(11):2651-2660. http://dx.doi.org/10.2166/wst.2013.146

Hileman, J., P. Hicks, and R. Jones. 2016. An alternative framework for analysing and managing conflicts in integrated water resources management (IWRM): linking theory and practice. International Journal of Water Resources Development 32(5):675-691. http://dx.doi.org/10.1080/07900627.2015.1076719

Horsbøl, A. 2018. Co-creating green transition: how municipality employees negotiate their professional identities as agents of citizen involvement in a cross-local setting. Environmental Communication 12(5):701-714. http://dx.doi.org/10.1080/17524$\underline{032.2018 .1436580}$

Huitema, D., E. Mostert, W. Egas, S. Moellenkamp, C. PahlWostl, and R. Yalcin. 2009. Adaptive water governance: assessing the institutional prescriptions of (co-)adaptive management from a governance perspective and defining a research agenda. Ecology and Society 14(1):26. http://dx.doi.org/10.5751/ES-02827-140126

Kauneckis, D., and K. Andersson. 2009. Making decentralization work: a cross-national examination of local governments and natural resource governance in Latin America. Studies in Comparative International Development 44(1):23-46. http://dx. doi.org/10.1007/s12116-008-9036-6

LaVanchy, G. T., S. T. Romano, and M. J. Taylore. 2017. Challenges to water security along the "Emerald Coast": a political ecology of local water governance in Nicaragua. Water 9(9):655. https://doi.org/10.3390/w9090655

Lebel, L., P. Garden, and M. Imamura. 2005. The politics of scale, position, and place in the governance of water resources in the Mekong region. Ecology and Society 10(2):18. http://dx.doi. org/10.5751/ES-01543-100218

Lebel, L., E. Nikitina, C. Pahl-Wostl, and C. Knieper. 2013. Institutional fit and river basin governance: a new approach using multiple composite measures. Ecology and Society 18(1):1. http:// dx.doi.org/10.5751/ES-05097-180101

Lubell, M., and L. Lippert. 2011. Integrated regional water management: a study of collaboration or water politics-as-usual in California, USA. International Review of Administrative Sciences 77(1):76-100. http://dx.doi.org/10.1177/0020852310388367

Malheiros, T. F., M. Guimarães Prota, and M. A. Perez Rincón. 2013. Participação comunitária e implementação dos instrumentos de gestão em bacias hidrográficas. Revista Ambiente \& Água - An Interdisciplinary Journal of Applied Science 8 (1):98-118.

Mancilla García, M. 2017. Negotiating in the absence of trust: exploring the interactions between officials and residents in a waste management project in Copacabana, Bolivia. Local Environment 22(6):667-681. http://dx.doi.org/10.1080/13549839.2016 .1252319

Mancilla García, M., and Ö. Bodin. 2019a. Participation in multiple decision making water governance forums in Brazil enhances actors' perceived level of influence. Policy Studies Journal 47(1):27-51. http://dx.doi.org/10.1111/psj.12297

Mancilla García, M., and Ö. Bodin. 2019b. Participatory water basin councils in Peru and Brazil: expert discourses as means and barriers to inclusion. Global Environmental Change 55:139-148. https://doi.org/10.1016/j.gloenvcha.2019.02.005

Ministry of Finance, Government of Sweden. 2017. Förordning (2017:868) med länsstyrelseinstruktion. SFS No. 2017:868. Government of Sweden, Stockholm, Sweden.

Ministry of the Environment and Energy, Government of Sweden. 1997. Miljöbalk Prop. 1997/98:45. Government of Sweden, Stockholm, Sweden.

Ministry of the Environment and Energy, Government of Sweden. 1998a. Förordning om avgifter för prövning och tillsyn enligt miljöbalken. SFS No. 1998:940. Government of Sweden, Stockholm, Sweden.

Ministry of the Environment and Energy, Government of Sweden. 1998b. Miljöbalk (1998:808). SFS No. 1998:808. Government of Sweden, Stockholm, Sweden. 
Ministry of the Environment and Energy, Government of Sweden. 2006. Lag (2006:412) om allmänna vattentjänster. SFS No. 2006:412. Government of Sweden, Stockholm, Sweden.

Ministry of the Environment and Energy, Government of Sweden. 2017a. Förordning (2017:872) om vattendelegationer. SFS No. 2017:872. Government of Sweden, Stockholm, Sweden.

Ministry of the Environment and Energy, Government of Sweden. 2017b. Miljötillsyn och sanktioner - en tillsyn präglad av ansvar, respekt och enkelhet, SOU 2017: 63. Government of Sweden, Stockholm, Sweden.

Naturvårdsverket. 2012. Styrmedel för ökad rening från kommunala reningsverk: För genomförande av aktionsplanen för Östersjön och Kattegatt samt miljökvalitetsnormer för kväve och fosfor. Rapport 6521. Naturvårdsverket, Stockholm, Sweden.

Newig, J., D. Schulz, and N. W. Jager. 2016. Disentangling puzzles of spatial scales and participation in environmental governance - the case of governance re-scaling through the European Water Framework Directive. Environmental Management 58:998-1014. http://dx.doi.org/10.1007/s00267-016-0753-8

Normas Jurídicas de Nicaragua. 2010. Reglamento de la Ley No. 620, “Ley General de Aguas Nacionales." Asamblea Nacional de Nicaragua, Managua, Nicaragua. [online] URL: http:// legislacion.asamblea.gob.ni/Normaweb.nsf/4c9d05860ddef1c50625725e0051e506/9f2f848b62c936d1062577b2005f30a9? OpenDocument

Ostrom, E. 2010. Polycentric systems for coping with collective action and global environmental change. Global Environmental Change 20(4):550-557.

Pahl-Wostl, C., P. Jeffrey, N. Isendahl, and M. Brugnach. 2011. Maturing the new water management paradigm: progressing from aspiration to practice. Water Resources Management 25 (3):837-856. http://dx.doi.org/10.1007/s11269-010-9729-2

Pierre, J., A. Røiseland, B. G. Peters, and A. Gustavsen. 2017. Comparing local politicians' and bureaucrats' assessments of democratic participation: the cases of Norway and Sweden. International Review of Administrative Sciences 83(4):658-675. http://dx.doi.org/10.1177/0020852315598214

Presidência da República, Casa Civil, Subchefia para Assuntos Jurídicos. 1997. Lei $N^{\circ}$ 9,433, de 8 de Janeiro de 1997. Presidência da República, Brasília, Brazil. [online] URL: http://www. planalto.gov.br/ccivil 03/Leis/L9433.htm

Ribeiro, C. R. 2015. The municipality and the integrated management of the urban space and the water resources: the case of Juiz De Fora (MG). Pages 1-8 in Simpósio Brasileiro de Recursos Hídricos. Associação Brasileira de Recursos Hídricos, Brasília, Brazil.

Varis, O., K. Enckell, and M. Keskinen. 2014. Integrated water resources management: horizontal and vertical explorations and the 'water in all policies' approach. International Journal of Water Resources Development 30(3):433-444. http://dx.doi. org/10.1080/07900627.2014.912130

Wyborn, C., and R. P. Bixler. 2013. Collaboration and nested environmental governance: scale dependency, scale framing, and cross-scale interactions in collaborative conservation. Journal of Environmental Management 123:58-67. http://dx.doi.org/10.1016/ j.jenvman.2013.03.014 